F. med. Genet. (I966). 3, 203.

\title{
The Use of the Surname as a Genetic Marker in Wales
}

\author{
DAVID J. B. ASHLEY and H. DUNCAN DAVIES
}

From Morriston Hospital, Swansea

To some extent the population of the Principality of Wales, especially the industrial areas of South East Wales, is heterogeneous, comprising the Welsh, descended from the long-standing inhabitants of this part of the world and the immigrants who have arrived mostly within the past hundred or so years. The two populations live in the same physical environment and, in the industrial social milieu, tend to work side by side in the factories and mills, though it is possible that the traditional craft of coal-mining claims a higher proportion of Welshmen than do some of the newer industries.

It would be interesting and useful if these two populations could be identified by some easy marker so that the proportions of Welsh and non-Welsh could be assessed in relation to their illnesses, immunities, and other possibly genetically determined traits. The typical Welshman tends to be short in stature, long-headed, black-haired, and pale-faced, and many of us can readily call to mind such an individual. Unfortunately, however, many men of English descent have similar physical characteristics and many Welshmen are burly of figure and ruddy of complexion. Physical assessment is a notoriously unreliable method of assigning individual people into broad categories if a large block of 'middlemen' is not to be avoided, and it is extremely difficult, vide the problems of the colour bar, to define exact parameters which may be applied in such a context. The second character of the Welshman, not commonly acquired by immigrants, is the use of the Welsh language. It may fairly be suggested that one who speaks Welsh is a Welshman, the occasional exception serving only to underline the general truth of the assertion. In the present series only 9 of 231 people born outside Wales were Welsh speaking. Command of the Welsh language is, however, rarely recorded as a descriptive item in hospital case notes, with which we are principally concerned, and the character becomes useless for retrospective investigation and hardly more useful for prospective

Received September 14, 1965. investigations involving more than a small number of people. In very large-scale inquiries involving the whole of the country, the proportion of Welshspeaking people in different areas may prove useful where whole counties can be taken as the units of investigation. For example, in the County of Carmarthen more than $70 \%$ of the men over the age of 45 claim to be Welsh-speaking, whereas in the County of Brecknock $36 \%$ do so and in Monmouth only $5.5 \%$ speak this tongue.

The final, easily determined, character, and the one on which this investigation is based, is the surname. The surname can, in males, be regarded as a character inherited in the holandric manner. A man hands on his surname to his sons, as he does his $\mathrm{Y}$ chromosome, and they in turn pass it on to their sons. The number of surnames in use among Welshmen is small, and each is characteristically derived from a Christian name: Davies, Evans, Thomas, Williams, Owens, Roberts, and Phillips, by the simple use of the genitive case, and others, Price, Pritchard, Pugh, and Parry, for example, by elision of the Welsh prefix Ap 'the son of'. In contrast English surnames most often derive from place names, as does Ashley; from occupations, Smith, Weaver, Miller; or from nicknames, Armstrong, White, Black, and Small. The characteristic Welsh surnames have been used (Legon, 1963) in an observation on the frequency of gastric carcinoma in the Welsh and non-Welsh inhabitants of North Wales. The present investigation is an attempt to validate the use of this parameter as a marker by which the two components of a heterogeneous population may to some extent be separated.

\section{Methods and Procedures}

A questionnaire was circulated among a miscellaneous group of the male inhabitants of Swansea and the surrounding districts. Each man was asked to give his name, address, and age, his mother's maiden name, the place of birth of himself and his two parents, and whether or not he and his parents were Welsh-speaking. In all 558 completed forms were analysed. In most cases all the information requested was available; in a 
few, one or more of the data were not known. Some of the older men were, for example, unable to cite the place of birth of their parents. Two groups were established, those with Welsh surnames and those without.

The names classified by us as Welsh were 96 in number and were selected from lists of Welsh names such as that of Watkin (1956), by our general knowledge of the Welsh people and their names, and from lists suggested by various colleagues. All other names were arbitrarily assigned as non-Welsh. It is recognized that there are occasional names of Welsh origin not included in the present list, but these are rare. Similarly it is appreciated that a non-Welsh name may have been introduced into a Welsh family by a single non-Welsh male many generations previously. These too are rare and do not introduce serious errors when a statistical analysis is carried out. The list of names is set out in the Appendix. A smaller group comprising the 34 most common names was used for some early analyses. The names in this group are designated by an asterisk in the main list of names.

Professor Cochrane kindly gave us access to the protocols of a sample survey of just over 1,000 miners and ex-miners aged between 35 and 64 living in the Rhondda Fach, a mining valley in South Wales, carried out by Professor I. T. T. Higgins (Higgins, Oldham, Kilpatrick, Drummond, and Bevan, 1963). Data were available in respect of each man for height, weight, $\mathrm{ABO}$ and $\mathrm{Rh}$ blood group, secretor status, hair colour and eye colour, smoking habits, the stated nationality of the subject and his two parents, and in many instances the ability or otherwise to taste phenylthiocarbamide. These data have been analysed with reference to the surnames of the people concerned, and are presented together with data obtained in local surveys in the Swansea area.

\section{Results}

Welsh Speaking and Welsh Surnames. The data relevant to speaking Welsh are set out in Table I. The ability to speak Welsh was very strongly associated with the Welsh surname in all subdivisions of this Table $(p<0.001$ in each instance). This was true of the men who filled in the questionnaire, of each of their parents separately, and of a composite group of older subjects formed by combining the men over the age of 40 and all the fathers and mothers, classified by their maiden names, in the series. When the family units were considered, a high proportion ( $86 \%$ ) of families in which all members were Welsh speaking had Welsh family names, while in the group of families in which no member spoke Welsh, only $32 \%$ had Welsh surnames.

These findings indicate that the Welsh surnames can be used as a marker which, in the population living in this area, indicates 'Welshness' in so far as Welsh-speaking is concerned.
TABLE I

ASSOCIATION BETWEEN WELSH NAME AND
WELSH-SPEAKING

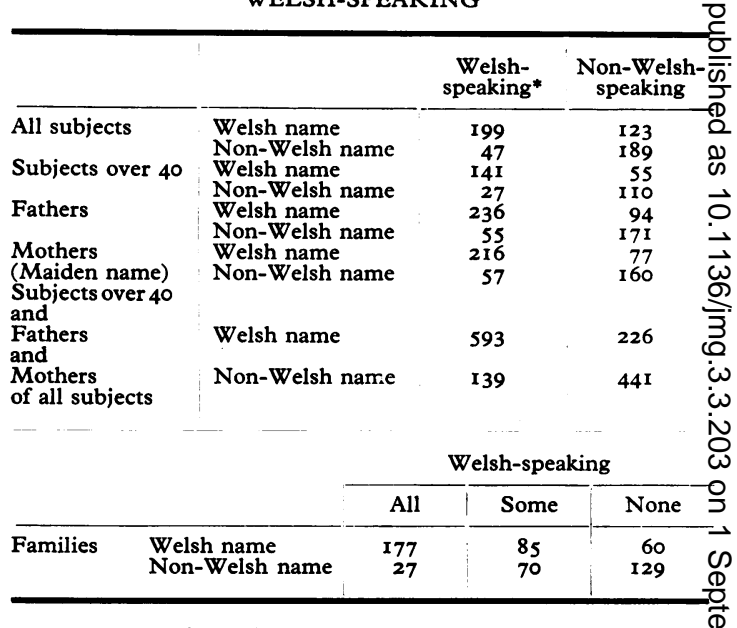

*Data on Welsh speaking were not available on two fathers and 48 mothers.

The ability to speak Welsh is more often acquired from a Welsh-speaking mother than from a Welsh-o speaking father when the mother speaks onlys English, as when a child is learning to talk he is much more often in the company of his mother than of his father. This is borne out by the data from? this series. In only 16 instances did a man speak Welsh while his mother was unable to do so. This group included the only 6 instances where the man who filled in the questionnaire was the only membe? of the family to be Welsh-speaking, but in 29 instances a man questioned spoke Welsh which was not the tongue of his father. In 40 families the father was the only Welsh-speaking member and in 30 the mother only spoke the language. These were predominantly dwellers in the town of Swansea where there is some environmental pressure agains 5 Welsh-speaking among children, unless thein parents are possessed of sufficient perseverance to․ continue to use the language within the family circle. Among the men of non-Welsh surnames who were able to speak Welsh, the influence of thein mothers was also apparent (Table II). A significantly higher proportion of those speaking Welsh had mothers whose maiden names were included in the group of Welsh names.

The majority of those questioned were born inf? Wales. 48 of the men concerned, 81 of their mothers, and 93 of their fathers were born elsewhere than the Principality, and only 9 of these were able to speaks 
TABLE II

ASSOCIATION OF WELSH-SPEAKING WITH MOTHER'S MAIDEN NAME

\begin{tabular}{lcc}
\hline $\begin{array}{c}\text { Mother's } \\
\text { Maiden } \\
\text { Name }\end{array}$ & \multicolumn{2}{c}{ Men with Non-Welsh Surnames } \\
\cline { 2 - 3 } & Welsh-speaking & Non-Welsh-speaking \\
\hline Welsh & 28 & 60 \\
Non-Welsh & 13 & I I4 \\
\hline
\end{tabular}

Welsh. In 32 families with Welsh surnames some member was born outside Wales, and in 100 families with non-Welsh surnames some member was born outside Wales. In 30 of the families with non-Welsh names, all members were born outside Wales, while in only one family with a Welsh name were all members born outside Wales. These differences are highly significant $(p<0.001)$.

The data were also analysed to determine the extent to which the choice of marriage partner among the parents of the propositi was determined by Welshness. There is an association between Welsh-speaking in the father and the mother. $80 \%$ of the Welsh-speaking fathers had Welshspeaking wives while only $23.5 \%$ of the non-Welshspeaking fathers had wives who spoke Welsh. This is highly significant both for the case of propositi over the age of 40 and for those in the younger age-group $(p<0.001)$. In Table III the family surnames are compared with the maiden names of the mothers. There is a high degree of association between the father's surname and the mother's maiden name in the group of propositi over the age of $40(p<0.001)$, but the association, while still significant $(0.02>p>0.01)$, is less so for the younger age-groups. These associations are due to a similarity of interests between Welshspeaking people and also, possibly, to positive pressure being brought to bear on a young man or young woman to ensure that he or she selects a partner acceptable to the remainder of the family.

The degree of separation of the two components of this heterogeneous population is, however, steadily decreasing. A series of 425 female hospital patients, whose addresses were given as Swansea, and whose married and maiden names were known, was examined. In 236 instances either the married or maiden name was Welsh while the other was not. The proportion of these mixed marriages decreased with increasing age.

Stated Nationalities. In the Rhondda survey all the men were asked to state the nationality, English, Welsh, Scots, Irish, or other, of themselves and of their two parents (Table IV). An overwhelming preponderance of both those with Welsh names and those with non-Welsh names regarded themselves as Welsh. This to some extent may be an assumption of nationality by residence rather than a claim of nationality by birth. Those with Welsh names in more than $90 \%$ of instances claimed also that their fathers and mothers were Welsh, and in only a small proportion of cases did a man state that neither he nor either of his parents was of Welsh nationality. In the case of men with non-Welsh names they stated that the nationality of their fathers was something other than Welsh in almost $50 \%$ of the cases, and claimed only about $70 \%$ of their mothers to be Welsh. In only $50 \%$ of instances did these men claim that they themselves and both parents were of Welsh nationality.

TABLE III

ASSOCIATION OF WELSH NAMES BETWEEN PARENTS

\begin{tabular}{l|cc}
\hline & Mother's Maiden Name \\
\cline { 2 - 3 } Family Name & Welsh & Non-Welsh \\
\hline Welsh & 206 & 100 \\
Non-Welsh & 88 & 127 \\
Son under 40 & 139 & 52 \\
Welsh & 53 & 70 \\
Non-Welsh & 67 & 48 \\
Son over 40 & 35 & 57 \\
Welsh & & \\
Non-Welsh & &
\end{tabular}

TABLE IV

RHONDDA SERIES: STATED NATIONALITIES PERCENTAGE CLAIMING WELSH

\begin{tabular}{|c|c|c|c|c|c|}
\hline Age-group & Self & Fa:her & Mother & $\begin{array}{c}\text { All } \\
\text { Three }\end{array}$ & None \\
\hline \multicolumn{6}{|l|}{ Welsh name } \\
\hline $\begin{array}{l}35-44 \\
45-54 \\
55-64 \\
\text { Non-Welsh name }\end{array}$ & $\begin{array}{l}100 \\
99 \\
97 \cdot 5\end{array}$ & $\begin{array}{l}96 \\
95 \\
96\end{array}$ & $\begin{array}{l}92 \\
94 \\
95\end{array}$ & $\begin{array}{l}89 \\
92 \\
93\end{array}$ & $\begin{array}{l}0 \\
\text { I } \\
2\end{array}$ \\
\hline $\begin{array}{l}35-44 \\
45-54 \\
55-64\end{array}$ & $\begin{array}{l}92 \cdot 5 \\
89 \\
83\end{array}$ & $\begin{array}{l}56 \cdot 5 \\
57 \cdot 5 \\
49\end{array}$ & $\begin{array}{l}71 \cdot 5 \\
72 \\
63\end{array}$ & $\begin{array}{l}49 \cdot 5 \\
52 \\
46\end{array}$ & $\begin{array}{r}7.1 \\
6.6 \\
16.6\end{array}$ \\
\hline
\end{tabular}

TABLE V

WELSH NAMES AND SOCIAL CLASS

\begin{tabular}{|c|c|c|c|c|}
\hline \multirow{2}{*}{$\begin{array}{l}\text { Social } \\
\text { Class }\end{array}$} & \multicolumn{2}{|c|}{ Men under 50} & \multicolumn{2}{|c|}{ Men over 50} \\
\hline & $\begin{array}{l}\text { Welsh } \\
\text { Name }\end{array}$ & $\begin{array}{l}\text { Non-Welsh } \\
\text { Name }\end{array}$ & $\begin{array}{l}\text { Welsh } \\
\text { Name }\end{array}$ & $\begin{array}{c}\text { Non-Welsh } \\
\text { Name }\end{array}$ \\
\hline $\begin{array}{l}\text { Stable middle class } \\
\text { Stable working class } \\
\text { Occupational class }\end{array}$ & $\begin{array}{r}21 \\
\text { I I0 }\end{array}$ & $\begin{array}{r}30 \\
199\end{array}$ & $\begin{array}{l}18 \\
94\end{array}$ & $\begin{array}{r}23 \\
147\end{array}$ \\
\hline $\begin{array}{l}\text { I and II } \\
\text { Occupational class }\end{array}$ & 44 & 62 & 45 & 53 \\
\hline IIIb, IV, and V & 130 & 131 & 119 & 176 \\
\hline
\end{tabular}


It is appreciated that a statement of nationality, particularly where there are no legal formalities attached to the assumption of Welsh, English, or other subdivision of British nationality, is the least accurate assessment of the ethnic group to which a man may belong. The difference, however, in the stated nationality of the parents is striking and probably reflects the origin of men with non-Welsh names from families outside the Principality.

Selected Welsh Populations. Additional data were sought from a study of four populations regarded by us as highly selected for Welshness. In the list of officials of the National Eisteddfod of I963 at Llandudno, 209 names were recorded. Of these, 177 were included in our list of Welsh names and only 32, each of which was represented only once, were not. The latter included adjudicators for competitions in some of the less typically Welsh crafts. A similar analysis of the names recorded in the membership list of the Gorsedd for 1963 showed 814 names of which 738 were included in our list of Welsh names and only 76 were not. In 8 instances a non-Welsh name appeared more than once in the list.

A collection of annual reports from Welshspeaking chapels was made available to us by the Department of Social Sciences at the University College of Swansea. It was felt that membership of such a chapel was probably one of the strongest indices of Welshness which could readily be obtained, and the reports were scrutinized to determine the proportion of members bearing names which we had selected as Welsh. In these chapels services and business are conducted in the Welsh language, and there is a pronounced tendency to uphold Welsh cultural traditions. Many chapel members and ministers are officials of the National and Local Eisteddfodau and are interested in the Welsh language newspapers, and books, which are presently published. 69 ministers were appointed to the chapels whose reports were available. Of these, $62(90 \%)$ had names included in our list. The lay officers of the chapels, the deacons, also showed a great preponderance of Welsh names. Out of a total of 830 names recorded, 713 were included in the list of Welsh names $(86 \%)$. Similarly the lists of subscribers of 9 of the larger congregations were examined and showed that $80 \%$ ( 1458 out of 1818 ) had names included in our list of Welsh names.

In the County Borough of Swansea there are two Welsh schools in which the teaching and all school business is conducted in Welsh. The criterion for accepting a child at one of these schools is that Welsh shall be the language of the home. It is our view that, in addition, the parentson who must make a special request for their childres to be educated in this way, are strongly oriented towards the Welsh language and culture. Analysisis of the roles of these two schools shows that of $26 \%$ children on the register, $204(76 \%)$ had nameş which we included in our provisional list of 34 of the commonest Welsh names.

Environmental Differences. Two sets of data, on the social status of men in Swansea witls Welsh and non-Welsh names and on the smoking habits of the miners in the Rhondda Fach were्w available.

Social Status. Mr. C. C. Harris of the Departo ment of Social Science, University College, Swan? sea, very kindly made available to us some datas from a survey of a $2 \%$ sample of the population of Swansea made in connexion with a separate piece oळ research (Rosser and Harris, 1965). These dat? were anlysed in respect to the sub-sample of the 3\$ commonest Welsh names, marked with an asterisk in the Appendix. Table $\mathrm{V}$ shows that the propor: tion of individuals with Welsh names was slightly higher in the group designated stable middle classo i.e. those men in middle class occupations whose parents were in the middle class, than in the group of stable working class, i.e. the group in which the men were of working class occupations and theip parents were also of working class occupations $\overrightarrow{\overrightarrow{0}}$ This difference is not statistically significant 3 Classification of the present occupation under the Registrar-General's classification shows no signifi? cant difference between the proportion of men with Welsh names in occupations of Registrar-General' classes $I$ and 2 and the Registrar-General's classifi cations $3 \mathrm{~b}, 4$, and 5 . The income levels of the groups with and without Welsh names were almose identical. In the case of men under 50, those witk Welsh names had a mean income of $£$ r3.79 pef week, those with non-Welsh names had a mean income of $£_{13} .73$ per week. In the case of mer. over 50 those with Welsh names had a mean income of $£$ r3.6I per week, those with non-Welsh names had a mean income of $£_{11} \cdot 78$ per week.

Smoking Habits. Data on the smoking habits o the majority of men in the Rhondda series weree analysed. In the case of carcinoma of the lungd cigarette smoking is generally considered to be an important aetiological agent and the use of tobacco in this form has been inculpated in a variety of other common conditions. The numbers and 
TABLE VI

SMOKING HABITS

\begin{tabular}{lcc}
\hline & $\begin{array}{c}\text { Welsh } \\
\text { Name }\end{array}$ & $\begin{array}{c}\text { Non-Welsh } \\
\text { Name }\end{array}$ \\
\cline { 2 - 3 } Non-smoker & 63 & 59 \\
Manufactured cigarettes & 445 & 369 \\
Pipe & 35 & 27 \\
Hand-rolled cigarettes & 34 & 16 \\
Mean number of cigarettes per day & $13 \cdot 6$ & $14 \cdot 3$ \\
Mean numbers of ounces of pipe & $2 \cdot 1$ & $2 \cdot 0$ \\
tobacco per week & & \\
\hline
\end{tabular}

proportions of men who were non-smokers, smokers of manufactured cigarettes, pipe-smokers, and smokers of cigarettes which they made themselves, are shown in Table VI. There is no significant difference between the two groups, those with and those without Welsh names, and there is no significant difference in the mean number of cigarettes smoked per day in the case of cigarette smokers or the mean number of ounces of tobacco smoked per week.

Genetic Differences. The blood groups, secretor status, the ability to taste phenylthiourea, and the less well-defined genetic parameters, height and weight, hair and eye colour, were analysed for individuals in one or other of the series.

$A B O$ Blood Groups. The ABO blood groups had been determined on IO6I of the men in the Rhondda sample, and to this were added a total of 9652 blood group determinations on males and young unmarried females carried out during the past Io years in the laboratories at Morriston Hospital, Swansea. Gene frequencies were calculated by the method of Fisher (Race and Sanger, 1958). The data for blood group numbers and gene frequencies are set out in Tables VII and VIII. In the case of the hospital series the blood groups were determined on samples of blood from patients at the hospital, and were subdivided according to the place of residence into those whose home was in the County Borough of Swansea, and those whose home was in the Administrative Counties of Glamorgan and Carmarthenshire. The Glamorgan group consisted predominantly of patients living in Western Glamorgan in the areas Neath, Port Talbot, the Swansea valley, and the Gower Peninsula. The group which resided in Carmarthenshire came mostly from Eastern Carmarthenshire, the Borough

TABLE VII

ABO GROUPS-MORRISTON SERIES

\begin{tabular}{|c|c|c|c|c|c|c|c|c|c|c|c|}
\hline \multirow[b]{2}{*}{$\begin{array}{l}\text { Place of } \\
\text { Residence }\end{array}$} & \multirow[b]{2}{*}{$\begin{array}{c}\text { Date of } \\
\text { Birth }\end{array}$} & \multicolumn{5}{|c|}{ Welsh Name } & \multicolumn{5}{|c|}{ Non-Welsh Name } \\
\hline & & $\mathrm{O}$ & A & B & $\mathrm{AB}$ & Total & $\mathrm{O}$ & A & B & AB & Total \\
\hline \multirow[t]{2}{*}{ Swansea } & \multirow[t]{2}{*}{$\begin{array}{r}-1899 \\
-1919 \\
1920\end{array}$} & $\begin{array}{l}269 \\
280 \\
289\end{array}$ & $\begin{array}{l}244 \\
263 \\
257\end{array}$ & $\begin{array}{l}51 \\
52 \\
57\end{array}$ & $\begin{array}{l}20 \\
18 \\
20\end{array}$ & $\begin{array}{l}584 \\
613 \\
623\end{array}$ & $\begin{array}{l}299 \\
308 \\
381\end{array}$ & $\begin{array}{l}250 \\
278 \\
354\end{array}$ & $\begin{array}{l}74 \\
67 \\
77\end{array}$ & $\begin{array}{l}25 \\
22 \\
36\end{array}$ & $\begin{array}{l}648 \\
675 \\
848\end{array}$ \\
\hline & & & & & & 1820 & & & & & 2171 \\
\hline \multirow[t]{2}{*}{ Carmarthenshire } & \multirow[t]{2}{*}{$\begin{array}{r}-1899 \\
-1919 \\
1920-\end{array}$} & $\begin{array}{l}271 \\
346 \\
287\end{array}$ & $\begin{array}{l}225 \\
270 \\
249\end{array}$ & $\begin{array}{l}67 \\
72 \\
66\end{array}$ & $\begin{array}{l}18 \\
31 \\
21\end{array}$ & $\begin{array}{l}581 \\
719 \\
623\end{array}$ & $\begin{array}{l}102 \\
117 \\
168\end{array}$ & $\begin{array}{r}84 \\
96 \\
126\end{array}$ & $\begin{array}{l}16 \\
27 \\
35\end{array}$ & $\begin{array}{r}9 \\
13 \\
16\end{array}$ & $\begin{array}{l}211 \\
253 \\
345\end{array}$ \\
\hline & & & & & & 1923 & & & & & 809 \\
\hline \multirow[t]{2}{*}{ Glamorgan } & \multirow[t]{2}{*}{$\begin{array}{r}-1899 \\
-1919 \\
1920-\end{array}$} & $\begin{array}{l}271 \\
311 \\
235\end{array}$ & $\begin{array}{l}232 \\
287 \\
185\end{array}$ & $\begin{array}{l}60 \\
79 \\
51\end{array}$ & $\begin{array}{l}26 \\
13 \\
15\end{array}$ & $\begin{array}{l}589 \\
690 \\
489\end{array}$ & $\begin{array}{l}162 \\
178 \\
205\end{array}$ & $\begin{array}{l}148 \\
149 \\
163\end{array}$ & $\begin{array}{l}28 \\
34 \\
44\end{array}$ & $\begin{array}{l}15 \\
20 \\
15\end{array}$ & $\begin{array}{l}353 \\
381 \\
427\end{array}$ \\
\hline & & & & & & 1768 & & & & & I I 6I \\
\hline
\end{tabular}

\begin{tabular}{|c|c|c|c|c|c|c|c|}
\hline Swansea & -1899 & $\stackrel{\mathrm{O}}{67.95}$ & A & $\begin{array}{c}B \\
6 \cdot 16\end{array}$ & O & A & $\begin{array}{c}\text { B } \\
7.94 \\
6.08\end{array}$ \\
\hline & -1919 & 67.50 & $26 \cdot 50$ & $6 \cdot 00$ & $67 \cdot 45$ & 25.58 & 6.98 \\
\hline Carmarthenshire & $\begin{array}{r}1920- \\
-1899\end{array}$ & $\begin{array}{l}08.09 \\
68.04\end{array}$ & $\begin{array}{l}25 \cdot 50 \\
24.01\end{array}$ & $\begin{array}{l}0.41 \\
7.95\end{array}$ & $\begin{array}{l}67 \cdot 32 \\
70 \cdot 13\end{array}$ & $\begin{array}{l}26.18 \\
24.57\end{array}$ & $\begin{array}{l}6 \cdot 49 \\
5 \cdot 30\end{array}$ \\
\hline & & $\begin{array}{l}69 \cdot 77 \\
67.75\end{array}$ & $\begin{array}{l}23 \cdot 32 \\
24 \cdot 84\end{array}$ & $\begin{array}{l}6.92 \\
7.39\end{array}$ & $\begin{array}{l}68 \cdot 56 \\
70 \cdot 31\end{array}$ & $\begin{array}{l}23.94 \\
22 \cdot 70\end{array}$ & $\begin{array}{r}7.50 \\
6.98\end{array}$ \\
\hline Glamorgan & $\begin{array}{r}-1899 \\
-1919 \\
1920-\end{array}$ & $68 \cdot 14$ & $\begin{array}{l}24.69 \\
25.67\end{array}$ & $\begin{array}{l}7 \cdot 17 \\
7 \cdot 95\end{array}$ & $68 \cdot 20$ & $\begin{array}{l}26 \cdot 14 \\
24.56\end{array}$ & $\begin{array}{l}5.66 \\
6.31 \\
7.08\end{array}$ \\
\hline $\begin{array}{l}\text { Carmarthenshire and } \\
\text { Glamorgan }\end{array}$ & $\begin{array}{r}1920- \\
-1899 \\
-1919 \\
1920-\end{array}$ & $\begin{array}{l}69 \cdot 21 \\
68 \cdot 10 \\
68 \cdot 18 \\
68 \cdot 40\end{array}$ & $\begin{array}{l}23.65 \\
24 \cdot 35 \\
24.38 \\
24.31\end{array}$ & $\begin{array}{l}7 \cdot 14 \\
7 \cdot 56 \\
7 \cdot 43 \\
7 \cdot 28\end{array}$ & $\begin{array}{l}69 \cdot 30 \\
68 \cdot 92 \\
68 \cdot 89 \\
69 \cdot 78\end{array}$ & $\begin{array}{l}23 \cdot 57 \\
25 \cdot 55 \\
24 \cdot 31 \\
23.18\end{array}$ & $\begin{array}{l}7 \cdot 08 \\
5 \cdot 52 \\
6 \cdot 79 \\
7 \cdot 04\end{array}$ \\
\hline
\end{tabular}


TABLE VIII

ABO BLOOD GROUPS: RHONDDA SERIES

\begin{tabular}{|c|c|c|c|c|c|c|c|c|}
\hline \multirow{2}{*}{ Age } & \multicolumn{4}{|c|}{ Welsh Name } & \multicolumn{4}{|c|}{ Non-Welsh Name } \\
\hline & O & A & B & $\mathbf{A B}$ & 0 & A & B & $\mathbf{A B}$ \\
\hline \multirow[t]{3}{*}{$\begin{array}{l}35-44 \\
45-54 \\
55-64\end{array}$} & $\begin{array}{r}99 \\
51 \\
102 \\
\end{array}$ & $\begin{array}{r}105 \\
56 \\
82 \\
\end{array}$ & $\begin{array}{l}28 \\
14 \\
31\end{array}$ & $\begin{array}{l}9 \\
6 \\
9 \\
\end{array}$ & $\begin{array}{l}97 \\
55 \\
55 \\
\end{array}$ & $\begin{array}{l}96 \\
36 \\
70 \\
\end{array}$ & $\begin{array}{r}20 \\
11 \\
9 \\
\end{array}$ & $\begin{array}{l}8 \\
6 \\
6 \\
\end{array}$ \\
\hline & 252 & 243 & 73 & $24 / 592$ & 207 & 202 & 40 & $20 / 469$ \\
\hline & & & \multicolumn{6}{|c|}{ Gene Frequencies $\times 100$} \\
\hline \multicolumn{2}{|c|}{$\begin{array}{l}\text { Welsh Name } \\
\text { Non-Welsh Name }\end{array}$} & & \multicolumn{2}{|c|}{$\begin{array}{c}0 \\
65 \cdot 06 \\
66 \cdot 76\end{array}$} & \multicolumn{2}{|c|}{$\begin{array}{c}A \\
26 \cdot 12 \\
27 \cdot 08\end{array}$} & & $\begin{array}{c}B \\
8.82 \\
6.17\end{array}$ \\
\hline
\end{tabular}

of Llanelly, and the neighbouring areas in the Amman valley. The blood group frequencies in this last group could be compared with the blood group frequencies for blood donors with Welsh names in South Eastern Carmarthenshire (Watkin, 1956). In his group of 1269 donors, $48 \%$ were blood group $\mathrm{O}, 37 \%$ were group $\mathrm{A}$, and $\mathrm{II} \%$ were group B. In the present series of 1,923 hospital patients from similar areas of Carmarthenshire, $47 \%$ were blood group $\mathrm{O}, 38.6 \%$ were group $\mathrm{A}$, and $10.7 \%$ were group $B$. These two series are not significantly different. This indicates that the use of a large, mixed, hospital population is as valid as the use of blood donors in assessing the blood group frequencies in a geographical area. Consideration of the tables shows little difference in the frequency of group $O$ between the patients with Welsh names and those with non-Welsh names. The frequency of the $O$ gene is slightly higher in the more Westerly group, the series of patients in and around Swansea, than it is in the survey from the Rhondda. The frequency of gene $A$ is slightly higher among the non-Welsh than the Welsh for the older individuals in Carmarthenshire and Glamorganshire and for the miners and ex-miners from the Rhondda. The frequency of the gene B is higher in those with Welsh names than in those with non-Welsh names for Carmarthenshire, Glamorgan, and the group from the Rhondda. A trend is seen in the gene frequencies when the groups are subdivided by age. The excess of the $B$ gene is greatest in the older individuals, those between 55 and 65 in the Rhondda survey and those born before 1899 in the Swansea survey. This difference decreases with decreasing age until in the group of individuals under the age of 40 , those born since 1920, there is little difference between those with Welsh and those with non-Welsh names. Roberts (1942) reported the distribution of blood groups among blood donors in North Wales, and found a significant deficiency of the A gene among these people. Watkin (1956) made a survey base on the ABO blood groups of 16,760 donors beariag Welsh surnames drawn from all parts of Walss other than the industrial South and South Easit. He showed that there was a deficiency of the A geme in Northern and Central Wales, but that in South Wales the frequency of this gene corresponded to that in England. He also showed that there was $\overrightarrow{a m}$ increase in the frequency of the B gene in Central Wales, in Merioneth, and in parts of Denbighshis and in the Carmarthenshire area of South Wales. The results from the present series confirm that there is little difference in the frequency of thit gene $A$ but that the gene $B$ is more commonly sech in those with Welsh surnames than in those wi non-Welsh surnames and, furthermore, that the difference between the two groups is decreasing with time, that genetic intermingling, reflected by the proportions of the blood groups, is proceedieg in the population.

Rh Blood Groups. Data on the Rh blood groups, positive and negative only, were available for I,07I men in the Rhondda series and for the grow of just over 9,000 blood groups determined in the laboratory at Morriston. The results are set oot in Table IX, from which it will be seen that in 39 out of the 12 comparisons made, there was a higher proportion of Rhesus negative individuals in the group with non-Welsh names than in the grow with Welsh names. Summation of the whote series shows that $16 \%$ of those with Welsh names were Rhesus negative while $17 \%$ of those wi non-Welsh names were Rhesus negative. This difference for the 10,723 blood groups analysed significant at the $2 \%$ level.

TABLE IX

RHESUS BLOOD GROUPS

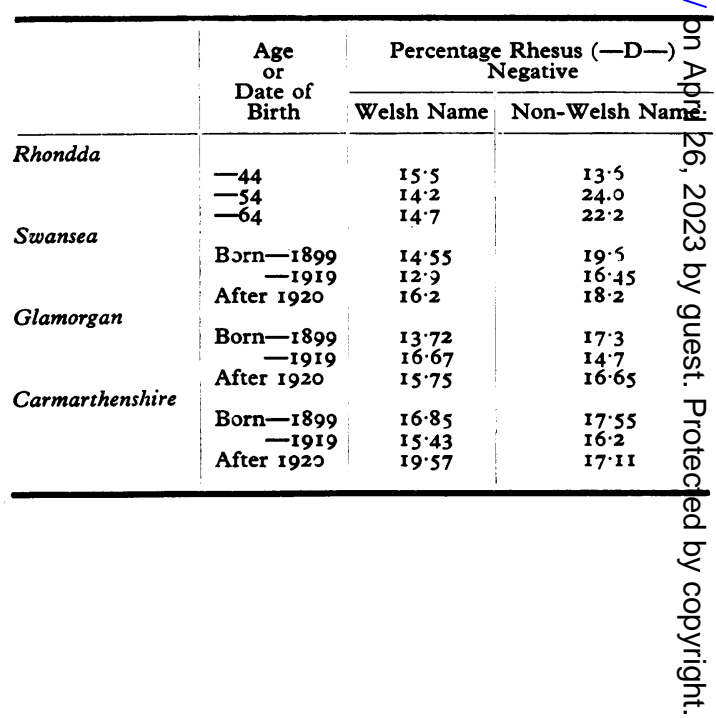


Secretor Status. The saliva from 1069 men in the Rhondda series had been analysed for the presence of blood group substance. Approximately $73 \%$ of all those tested were secretors of $\mathrm{ABO}$ blood group substance, $74 \%$ of those with Welsh names were secretors, $73 \%$ of those with non-Welsh names were secretors. This difference is not significant.

Taste Threshold. The threshold for tasting phenylthiocarbamide was established by the usual methods in 352 men. The results are set out in Table $\mathrm{X}$ and show no difference in taste threshold nor in the portion of non-tasters, those tasting only solutions I, 2, and 3, between the group with Welsh names and the group with non-Welsh names.

TABLE $\mathrm{X}$

THRESHOLD FOR TASTING PHENYLTHIOCARBAMIDE

\begin{tabular}{l|l|l|l|l|l|l|l|l|l}
\hline & \multicolumn{1}{c}{ Threshold } \\
\cline { 2 - 8 } & 1 & 2 & 3 & 4 & 5 & 6 & 7 & 8 & 9 \\
\hline $\begin{array}{l}\text { Welsh name } \\
\text { Non-Welsh name }\end{array}$ & 6 & 4 & 20 & 10 & 18 & 54 & 58 & 36 & - \\
\hline
\end{tabular}

Height and Weight. There was no difference in height and weight between the men with Welsh names and those with non-Welsh names (Table XI). In both groups there was a tendency for the younger men, i.e. those between 35 and 45 , to be taller by almost 2 inches $(5 \mathrm{~cm}$.), and heavier by almost Io $\mathrm{lb}$. $(4.5 \mathrm{~kg}$.) than their colleagues between 55 and 65 . This difference probably reflects the general temporal increase in height and weight seen elsewhere in the population.

TABLE XI

MEAN HEIGHT AND WEIGHT

\begin{tabular}{|c|c|c|c|c|c|c|}
\hline \multirow[b]{2}{*}{ Age } & \multicolumn{3}{|c|}{ Welsh Name } & \multicolumn{3}{|c|}{ Non-Welsh Name } \\
\hline & $35-44$ & $45-54$ & $55-64$ & $35-44$ & $45-54$ & $55-64$ \\
\hline $\begin{array}{l}\text { Height (cm.) } \\
\text { Weight (kg.) }\end{array}$ & $\begin{array}{l}67.8 \\
155\end{array}$ & $\begin{array}{l}66.89 \\
149.5\end{array}$ & $\begin{array}{r}65 \cdot 97 \\
145 \cdot 75\end{array}$ & $\begin{array}{r}67.6 \\
156.4\end{array}$ & $\begin{array}{l}67.04 \\
148.4\end{array}$ & $\begin{array}{l}65.69 \\
144\end{array}$ \\
\hline
\end{tabular}

Eye and Hair Colour. No difference was noticed in the eye colour between the men with Welsh surnames and those with non-Welsh surnames. In the case of hair colour (Table XII) there was a significant difference between those with Welsh names and those without. There was a deficiency of men with light brown/light-coloured hair in the
TABLE XII

HAIR COLOUR

\begin{tabular}{l|c|c}
\hline & Welsh Name & Non-Welsh Name \\
\hline Light & III & I 18 \\
Dark & 197 & 148 \\
Medium & 269 & 193 \\
Red & 12 & 8 \\
\hline
\end{tabular}

group with Welsh names compared with the group with non-Welsh names. This difference is significant at the $5 \%$ level.

\section{Discussion}

Analysis of the data presented in this paper confirms that a strong association exists between Welsh surnames and the possession of a Welsh cultural heritage manifested by the ability to speak the Welsh language, by an interest in the affairs of the Gorsedd, by participation in Welsh religious denominations, and by the use of the Welsh educational facilities. The two groups of individuals, those with Welsh names and those with non-Welsh names, show genetic differences in their blood groups. There was a higher frequency of the group $B$ gene in those with Welsh names, and a lower proportion of those with Welsh names were Rhesus negative. There was, too, a difference in hair colour; a smaller proportion of those with Welsh names had light-coloured hair than did those with non-Welsh names.

No differences were noted in the two groups for the characters of height, weight, secretor status, the ability to taste phenylthiocarbamide, and eye colour.

Differential susceptibility to disease may be attributed to environmental rather than to genetic causes. In order to determine whether there were environmental differences within the geographical environment of the industrial strip of South Wales, analyses were made of the social class, income, and smoking habits of those with Welsh and non-Welsh names. No significant differences were noted.

The usefulness of aids for separating Welsh and non-Welsh on the basis of their surnames is limited by the increasing fusion of the Welsh and nonWelsh populations shown by the increasing proportion of intermarriage between the two groups and by the trend towards equality in blood group frequencies. It is probable that such a method can only be applied in urban areas in the case of men over the age of 40 and 45 , whose parents were married during or before the 1914-18 war. In rural areas, where the proportion of Welsh people tends to be high, the method would be 
useful in a younger age-group. In the case of the women the maiden name is the only useful index and should be recorded when data, such as hospital records, are being compiled.

It is recognized that the method of selection of names is not an absolute criterion for the selection of the Welsh moiety of the local heterogeneous population, and that some individuals with Welsh surnames are not of the Welsh race, while some with non-Welsh surnames are of Welsh extraction and carry many of the Welsh genes. This, however, does not invalidate the use of the parameter but rather enhances its value, as a difference observed between the frequencies of a disease in the two named groups will reflect a greater difference in the frequencies of the disease in individuals who are truly 'Welsh' and 'non-Welsh'.

This can be shown quite simply. Let the group with Welsh names include a proportion $a \%$ who are Welsh, and the group with non-Welsh names include a proportion $b \%$ who are Welsh. Then $\mathrm{I}, 000$ individuals with Welsh names will comprise roa who are Welsh and I000 - IOa who are not Welsh, while a similar group with non-Welsh surnames will comprise rob who are Welsh and $1000-10 b$ who are non-Welsh. Let the true frequency of the character being studied be $f$ per I000 in the group of non-Welsh and $c f$ per 1000 in the group of Welsh. The number of cases seen in the group with Welsh names will then be:

$$
(\text { I000 - roa) } f+\text { roacf, }
$$

and the number of cases in the group with non-Welsh names will be:

$$
(1000-\mathrm{IO} b) f+\mathrm{Iobcf} \text {. }
$$

The ratio between these two numbers is the observed difference in rates between those with Welsh names and those with non-Welsh names:

$$
\begin{gathered}
\frac{(\mathrm{I} 000-\mathrm{IO} a) f+\mathrm{I} 0 a c f}{(\mathrm{I} 000-\mathrm{I} 0 b) f+\mathrm{I} 0 b c f} \\
\text { which reduces to, } \\
\frac{(\mathrm{I} 00-a)+a c .}{(100-b)+b c}
\end{gathered}
$$

The proportion of Welsh in the population with Welsh names may be expected to be higher than that in the population with non-Welsh names and can be expressed as $a=b+x$. The ratio then becomes:

$$
\frac{100-b-x+c(b+x)}{100-b+b c}
$$

which can be further reduced to,

$$
\mathrm{I}+\frac{x(c-\mathrm{I})}{\mathrm{I} 00+b(c-\mathrm{I})}
$$

When $x=0$, i.e. when the proportion of Welsh in the two populations is identical, the ratio between the number of cases in each population becomes equal to 1 When segregation is complete, when the populatio with Welsh names consists entirely of Welsh pepol and the population with non-Welsh names consist entirely of those who are not Welsh, $b=0$ and $x=\overline{\text { woc }}$ and the ratio reduces to $c$. In the intermediate cāses where some of the population with Welsh names $\overrightarrow{\pi a r}$ non-Welsh, the ratio between the numbers of cases ir the two groups lies between I and $c$. If the obsewwer ratio, which is less than $c$, indicates a significant differ ence, then the greater true ratio will also show: significant difference.

The potential uses of such a parameter, whic is easy to determine over large numbers of cases, manifold. It can reasonably be inferred thaf $\omega_{\text {if }}$ there is a difference in the incidence of a diserse between men with Welsh surnames and men witt. non-Welsh surnames that there is a racial or genetic factor operative in the aetiology of the disease in question, as environmental differences are aD a minimum. Our own studies in progress suggest that such differences exist in the case of cancer of the lung and of the stomach; that the one is dess common in Welshmen than in Englishmen, and the other more common. A further study of the distribution of the $\mathrm{ABO}$ blood groups indicates a difference between those with Welsh surnames those with non-Welsh surnames, and confirms by using the surname we are dividing our poptation into two genetically separate groups.

\section{Summary}

Evidence is adduced to support the hypothesis that the surname can be used as a marker for Welshness in the heterogeneous population Wales, and that this marker may be used in a studdy of the genetic components of illnesses, immunitges, and other traits of the population of the Principality. It is emphasized that mingling of the population is occurring at an increasing rate, and that the technique though it is valid now will probably not be so in one or two generations.

We gratefully acknowledge the help of $\mathrm{Mr}$. Christo hher Harris, M.A., of the Department of Social Science of University College Swansea, Professor A. L. Cochfiane of the Medical Research Council Epidemiological Research Unit, Professor T. J. Morgan of the University College Swansea, Mr. L. J. Drew, M.A., M. \$d., Director of Education of Swansea, and Miss D.NM. Evans and Mr. T. H. Davies, Heads of the Welsh Schools of Swansea.

The investigation was financed by a grant from 9 Research Funds of the Welsh Hospital Board. 


\section{REFERENCES}

Higgins, I. T. T., Oldham, P. D., Kilpatrick, G. S., Drummond, R. J., and Bevan, B. (1963). Blood groups of miners with coalworkers' pneumoconiosis and bronchitis. Brit. F. industr. Med., 20, 324 .

Legon, C. D. (1963). Cancer in North Wales. Brit. med. F., 1, 265. Race, R. R., and Sanger, R. (1958). Blood Groups in Man, 3rd ed. Blackwell, Oxford.
Roberts, J. A. F. (I942). Blood-group frequencies in North Wales. Ann. Eugen. (Lond.), Ir, 260.

Rosser, C., and Harris, C. (1965). The Family and Social Change: a Study of Family and Kinship in a South Wales Town. Routledge and Kegan Paul, London.

Watkin, I. M. (1956). ABO blood groups and racial characteristics in rural Wales. Heredity, 10, 161 .

\section{Appendix}

\section{A List of Welsh Names Used in the Survey}

\begin{tabular}{|c|c|c|}
\hline Adda & ${ }^{\star}$ Griffith & *Morgan \\
\hline Anwyl & Gronow & ${ }^{\star}$ Morris \\
\hline Baynham & Gwatkin & ^Owen \\
\hline$\star$ Bevan & Gwilt & ^Parry \\
\hline Beddoe & Gwilym & $\star$ Phillip \\
\hline Bellis & Gwyn & Powell \\
\hline Beynon & Gwyther & Powis \\
\hline Bithel & ^Harries & $\star$ Price \\
\hline Blythin & ${ }^{\star}$ Hopkin & *Pritchard \\
\hline ^Bowen & Howell & Probert \\
\hline Breese & ^Hughes & Probyn \\
\hline Cadarn & Humphries & Prosser \\
\hline Caddell & Idris & $\star$ Protheroe \\
\hline Cadwallader & Ithell & Prytherch \\
\hline Craddock & «James & ^Pugh \\
\hline David & $\star$ ¿Jenkin & $\star$ Rees \\
\hline$\star$ Davies & $\star$ John & ${ }^{\star}$ Richards \\
\hline Dilwyn & «Jones & ${ }^{\star}$ Roberts \\
\hline Edmonds & Joseph & Rogers \\
\hline Edmunds & Kenwyn & Rosser \\
\hline ^Edwards & Kyffin & Rowlands \\
\hline Elias & $\star$ ¿Lewis & ^'Thomas \\
\hline Ellis & Leyshon & Treharne \\
\hline ^Evans & ${ }^{\star}$ Llewellyn & Trevethan \\
\hline ^Eynon & ${ }^{\star}$ Lloyd & Tudor \\
\hline Foulk & Loughor & Vaughan \\
\hline Foulkes & Machen & ^Walters \\
\hline Francis & Maddock & $\star$ Watkins \\
\hline George & ${ }^{\star}$ Mainwaring & Welsh \\
\hline Gethin & Mathias & ${ }^{\star}$ Williams \\
\hline Glyn & Meredith & Wynn \\
\hline Gough & Meyrick & Yorath \\
\hline
\end{tabular}

